Ann. Biol. anim. Bioch. Biophys., 1978, 18 (4), 1007-1012.

\title{
Estrogens and estrogenic effects in Tilapia aurea (Cichlidae, Teleostei)
}

\author{
par Aviva TERKATIN-SHIMONY, Z. YARON
}

Department of Zoology, The George S. Wise Center for Life Sciences, Tel-Aviv University, Tel-Aviv, Israel.

Summary. Estradiol $\left(E_{2}\right)$ level in plasma of non-breeding female Tilapia aurea, measured by RIA, was $0.33 \pm 0.02 \mathrm{ng} / \mathrm{ml}$ (mean $\pm S E M, n=6$ ). This level is about $10 \mathrm{p}$. 100 of the level found in breeding females, about 4 times higher than in ovariectomized females and similar to the level found in non-breeding males.

Twenty-four hours following a single $i$. p. injection of $0.5 \mathrm{mg} E_{2}$, the estradiol level in plasma of ovariectomized Tilapia was within the physiological range $(0,2-10 \mathrm{ng} / \mathrm{ml})$. This level was maintained for at least 4 days. Comparison of the vitellogenic potency of 3 estrogens in ovariectomized $T$. aurea shows that estriol was more potent than estradiol, which, in furn, was more potent than estrone. Since $E_{2}$ increased in the plasma of estrone-injected fish, it is assumed that estrone was converted to estradiol in the recipient fish.

\section{Introduction.}

Raising water temperature above $22^{\circ}$ induces ovarian growth and spawning in Tilapia aurea (Fishelson, 1966). By employing the isotopic derivative technique it was shown that in female $T$. aurea exposed to $30^{\circ}$ the plasma level of testosterone, 11 ketotestosterone, $11 \beta$-hydroxytestosterone and deoxycorticosterone (DOC) is considerably higher than in females kept at $18^{\circ}$ (Katz and Eckstein, 1974). The increase of DOC level was explained by its possible role in the maturation of oocytes and ovulation, in line with the findings of Goswami and Sundararaj (1971) in Heteropneustes fossilis. However, the increased level of the three androgens remained unexplained. Also estrone $\left(E_{1}\right)$ and estradiol $-17 \beta\left(E_{2}\right)$ were isolated and identified in ovarian extracts of this fish, but they could not be detected in the peripheral plasma, using the isotopic derivative method (Katz ef al., 1971 ; Katz and Eckstein, 1974).

Studies on the functional significance of ovarian steroids in bony fishes have been hampered for a long time by the peculiar morphological organization of the ovary and oviduct. «Spaying a female teleost means in most cases that not only the source of the hormones is removed, but also an important part of the potential target organ. 》 (Reinboth, 1972.) However, $E_{2}$ is known to induce the synthesis and secretion of vitelloproteins by the liver in teleosts, as in other non-mammalian vertebrates (ChesterJones ef al., 1972 ; Campbell and Idler, 1976 ; Emmersen and Emmersen, 1976). 
In a recent reporf from our laboratory (Yaron ef al., 1977), we have shown that the plasma of Tilapia aurea contains immuno-reactive estradiol-17 $\beta(3.1 \pm 0.7 \mathrm{ng} / \mathrm{ml}$; mean $\pm S E M ; n=26$ ). The specificity of the antibody employed in our radioimmunoassay (RIA) was examined by cross-reaction with all the steroids previously reported in this species. The highest cross-reaction with $E_{2}$ was of $E_{1}(1.4$ p. 100). However, the similarity of $E_{2}$ determinations in whole versus chromatographically-separated plasma extract indicated that neither $E_{1}$ nor estriol $\left(E_{3}\right)$, if present in the plasma of this fish, could contribute to the $E_{2}$ determinations. A positive correlation was found between plasma $E_{2}$ level and ovarian weight. The plasma $E_{2}$ level dropped to $0.08 \pm 0.04 \mathrm{ng} / \mathrm{ml}$ nine days after ovariectomy. Concentrations of plasma calcium and proteins, indirect parameters of plasma vitelloprotein level, decreased following ovariectomy but could be restored to the initial level by injection of $E_{2}$.

This paper presents data on $E_{2}$ level in plasma of non-breeding females and males, compares the potency of $E_{1}$ and $E_{3}$ with that of $E_{2}$ on the above-mentioned vitellogenic parameters, and describes the disappearance of injected estradiol from the circulation of ovariectomized Tilapia.

\section{Materials and methods.}

Fish source, fish maintenance, surgery, blood sampling, protein, calcium and $E_{2}$ determinations were as described earlier (Yaron et al., 1977). Plasma $E_{2}$ was measured by RIA using the rabbit anti-17 $\beta$-estradiol-6-BSA-serum. For details on the technique, specificity and validity of the assay, the reader is referred to the latter article. Results are expressed as group means \pm SEM.

\section{Results and discussion.}

$E_{2}$ level in non-breeding $T$. aurea. Plasma $E_{2}$ level was measured in 6 fish of each sex collected after the breeding season (October) and kept for 10 days at $17^{\circ}$ and pholoperiod of $12 \mathrm{~L} / 12 \mathrm{D}$. The $E_{2}$ and protein levels were similar in both sexes $(p>0.05)$, but calcium level in the plasma of the females was higher than that of the males $(p=0.044$, table 1$)$.

TABLE 1

Estradiol, calcium and protein in plasma of non-breeding Tilapia aurea ${ }^{a}$

\begin{tabular}{ccccccc}
\hline \multirow{2}{*}{ Sex } & \multicolumn{2}{c}{$\mathrm{E}_{2}$} & \multicolumn{2}{c}{$\mathrm{Ca}$} & \multicolumn{2}{c}{ Protein } \\
\cline { 2 - 7 } & $\mathrm{n}$ & $\mathrm{ng} / \mathrm{ml}$ & $\mathrm{n}$ & $\mathrm{mg} \mathrm{p.} \mathrm{100}$ & $\mathrm{n}$ & $\mathrm{gr} \mathrm{p.} \mathrm{100}$ \\
\hline females $\ldots \ldots \ldots$ & 6 & $0.330 \pm 0.02$ & 6 & $13.64 \pm 0.80$ & 6 & $4.05 \pm 0.28$ \\
\hline males ......... & 6 & $0.516 \pm 0.086$ & 7 & $11.88 \pm 0.21 b$ & 7 & $4.33 \pm 0.24$
\end{tabular}

a) Fish were collected after the breeding season (October) and kept at $17^{\circ} \mathrm{C}$ for 10 days.

b) Significantly different from the female value $(p=0.044)$. Student's t-test. 
The $E_{2}$ level in non-breeding female $T$. aurea is about one-tenth of the level recorded in females kept at $25^{\circ}$ during the breeding season $(3.1 \pm 0.75 \mathrm{ng} / \mathrm{ml})$, but 4 times higher than that found in ovariectomized fish $(0.08 \pm 0.04 \mathrm{ng} / \mathrm{ml})$. The calcium concentration in the non-breeding females was higher than in males (table 1) and in ovariectomized fish (11.4 $\neq 0.2 \mathrm{mg}$ p. 100 ; Yaron et al., 1977). It is assumed, therefore, that $E_{2}$ is secreted by the ovary of non-breeding $T$. aurea and that their higher $\mathrm{Ca}$ level indicates the presence of vitelloprotein in the plasma even beyond the breeding season.

Disappearance of injected $E_{2}$ from circulation. - In many instances a relatively high dose of estrogen was required to elicit a pronounced vitellogenic effect. Since the physiological level of estrogen is rather low, such high doses as used in experimental procedures were justly criticized (Reinboth, 1972). The following experiment was performed in order to clarify the circulatory level of injected estradiol in T. aurea. For this study we used ovariectomized Tilapia of about $150 \mathrm{~g}$ body weight in which $E_{2}$ level was lower than $1 \mathrm{ng} / \mathrm{ml}$. Plasma levels of $E_{2}$ were measured 5, 24, 120 and $315 \mathrm{~h}$ following a single i. p. injection of $0.5 \mathrm{mg} E_{2}$ dissolved in sesame oil.

Five hours after the injection, plasma $E_{2}$ was extremely high (fig. 1). Between $24 \mathrm{~h}$ and $120 \mathrm{~h}$ the level of the exogenous steroid was within the physiological range, comparable to the levels encountered in female Tilapia with a gonadosomatic index of 1.8 to 4.0 (Yaron et al., 1977). The long intervals between samplings did not permit the calculation of the half-life for this steroid. It is obvious, however, that following an i. p. injection of $0.5 \mathrm{mg}$ to Tilapia the «pharmacological » level is sustained less than $24 \mathrm{~h}$, while in the 4 subsequent days the $E_{2}$ is maintained at a physiological level.

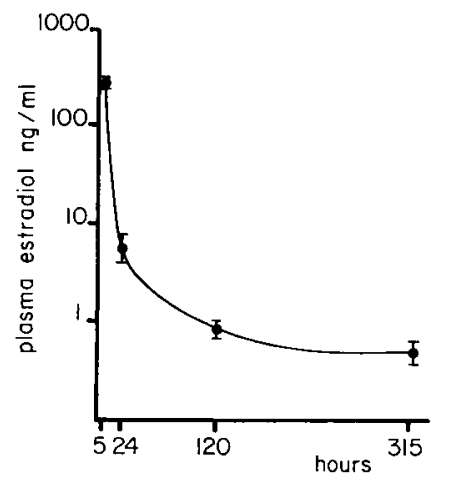

FIG. 1. - Disappearance of injected estradiol $-17 \beta$ from the circulation of Tilapia aurea. Estradiol-17 $\beta$ $\left(0.5 \mathrm{mg}, 1.2 \times 10^{-5} \mathrm{~mole} / \mathrm{kg} \mathrm{bw}\right)$ dissolved in sesame oil $(0.2 \mathrm{ml})$ was injected i. p. to 8 ovariectomized fish one month post operation.

Plasma $E_{2}$, Ca and protein following the injection of $E_{1}, E_{2}$ or $E_{3}$. - This experiment was designed to compare the estrogenic effects in $T$. aurea of three $C_{18}$ steroids known as estrogens in various vertebrates (Chester-Jones ef al., 1972). $\mathbf{E}_{1}, \mathbf{E}_{2}, \mathbf{E}_{3}$ or the vehicle $(1.3 \mathrm{ml} / \mathrm{kg})$ were injected i. p. $\left(1.3 \times 10^{-5} \mathrm{~mole} / \mathrm{kg} \mathrm{bw}\right)$ to female $T$. aurea one month after ovariectomy. Injections were repeated on days $3,6,10$ and 13 . Blood was sampled before the first injection, on day 10 before injection, and on day 18 . Plasma calcium and protein were determined as indirect parameters of the vitellogenic response to the injected estrogens (Yaron ef al., 1977). The results of day 10 and day 18 were averaged for each fish. For each pair of treatments, the means of these averaged 
levels were compared using Student's t-test (unequal variances). The highest vitellogenic response was found in fish treated with $E_{3}$. Treatment with $E_{1}$ was followed by an increase of the plasma calcium but not of protein. The effect of $E_{2}$ on these parameters was significant and similar to that reported earlier in this fish (Yaron et al., 1977) (fig. $2 a, b$ ).
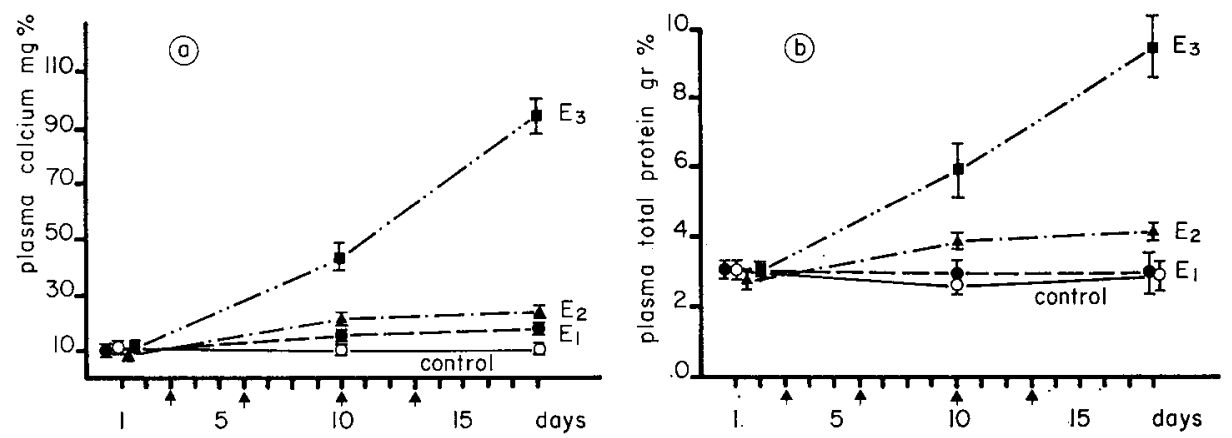

FIG. 2. - Vitellogenic parameters in Tilapia aurea injected with estrone, estrodiol or estriol. The steroids $\left(1.3 \times 10^{-5} \mathrm{~mole} / \mathrm{kg} \mathrm{bw}\right)$ dissolved in sesame oil $(1.3 \mathrm{ml} / \mathrm{kg})$ were injected i.p. to ovariectomized females (ca. $150 \mathrm{gr}$ bw) on days marked with arrows. Eight fish in each group. On day 10 blood was sampled before the injection. a) Plasma calcium ; b) Plasma protein.

In order to ascertain whether the vitellogenic effects of the steroids investigated resulted from the injected substances per se, the level of the immuno-reactive $E_{2}$ was measured in the plasma of fish from all groups (fig. 3). $E_{2}$ level in the plasma of oil-injected, ovariectomized fish remained low throughout the experiment. Similar levels were found in $E_{3}$-treated fish. It was not surprising to find higher $E_{2}$ levels in plasma of $E_{2}$ injected fish, but unexpectedly, the plasma $E_{2}$ level of $E_{1}$ injected fish increased significantly at day 10 and was similar to the level found in $E_{2}$-injected fish. This may indicate a conversion of the injected $E_{1}$ to $E_{2}$. The inter-conversion between these two steroids is a common phenomenon in vertebrate tissues (Ozon, 1972). If, indeed, the injected $E_{1}$ was promptly transformed into $E_{2}$ it would be difficult to explain

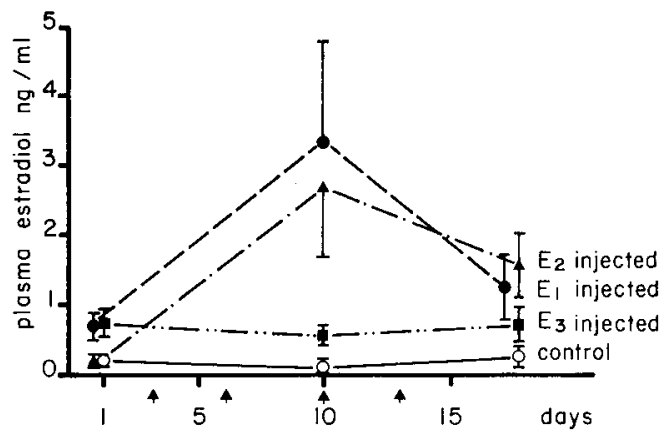

FIG. 3. - Plasma level of immuno-reactive estradiol in fish injected with $E_{1}, E_{2}, E_{3}$ or oil. Details as in figure 2. 
the low vitellogenic response to the injected steroid. We assume, therefore, that the increase of plasma $E_{2}$ in $E_{1}$-treated fish resulted from either : (i) a low rate of clearance and a consequent accumulation of $E_{1}$ in the plasma (a level of ca. $200 \mathrm{ng} / \mathrm{ml} E_{1}$ may be measured as ca. $3 \mathrm{ng} / \mathrm{ml} \mathrm{E}_{2}$ in the RIA used, due to a 1.4 p. 100 cross reaction) ; (ii) a conversion of estrone to an unknown steroid with an affinity to the antiserum similar to that of $E_{2}$ but with a low vitellogenic potency; (iii) the main conversion of $E_{1}$ to $E_{2}$ occuring close to day 10 after injection, and thus not yet allowing the manifestation of the vitellogenic response ; or (iv) a combination of these possibilities. Nevertheless, the high vitellogenic polency of $E_{3}$ may be attributed to this steroid per se, since no increase in plasma $E_{2}$ was detected in this group. It should be emphasized, however, that estriol has never been reported in Tilapia aurea.

Symposium sur la Reproduction des Poissons Paimpont, France, 19-21 septembre 1977.

Acknowledgements. - We would like to thank Professor H. Lindner and Dr. Fortune Kohen of the Hormone Research Department, the Weizmann Institute, Rehovol, for the antiserum used for the RIA. We also thank Professor P. F. Kraicer and Mr. Z. Ilan of Tel-Aviv University for their valuable discussion of the manuscript.

Résumé. Le niveau d'estradiol $\left(\mathrm{E}_{2}\right)$ dans le plasma de Tilapia aurea femelles en dehors de la période de reproduction, mesuré par dosage radioimmunologique, atteint $0,33 \pm 0,02 \mathrm{ng} / \mathrm{ml}$ (moyenne $\pm \mathrm{SEM}, \mathrm{n}=6$ ). II représente à peu près $10 \mathrm{p} .100 \mathrm{du}$ niveau trouvé chez les femelles au cours de cette dernière période ; il est environ 4 fois plus élevé que chez les femelles ovariectomisées et égal au niveau trouvé chez les mâles en dehors de la saison de reproduction.

Vingt-quatre heures après une seule injection intrapéritonéale de $E_{2}(0,5 \mathrm{mg})$, la concentration plasmatique d'estradiol de tilapia ovariectomisées est de l'ordre de celle trouvée chez les femelles normales $(0,2-10 \mathrm{ng} / \mathrm{ml})$. Ce niveau se maintient au moins 4 jours. La comparaison de l'effet vitellogénique des trois estrogènes chez les Tilapia aurea ovariectomisées montre que l'estriol est plus actif que l'estradiol, et ce dernier plus actif que l'estrone. Puisque $\mathrm{E}_{2}$ a augmenté dans le plasma de poissons ayant subi une injection d'estrone, ce composé a probablement été converti en estradiol par les poissons injectés.

\section{References}

CAMPBELL C. M., IDLER D. R., 1976. Hormonal control of vitellogenesis in hypophysectomized winter flounder (Pseudopleuronectes americanus Walbaum) Gen. comp. Endocr., 28, 143-150. CHESTER-JONES I., BELLAMY D., CHAN D. K. O., FOLLETT B. K., HENDERSON I. W., PHILLIPS J. G., SNART R. S., 1972. Biological actions of steroid hormones in nonmammalian vertebrates, 414-480. In IDLER D. R., Steroids in nonmammalian vertebrates. Acad. Press, New York and London.

EMMERSEN B. K., EMMERSEN J., 1976. Protein, RNA and DNA metabolism in relation to ovarian vitellogenic growth in the flounder Platichthys flesus (L.). Comp. Biochem. Physiol., 55B, 315-321.

FISHELSON L., 1966. Chichlidae of the genus Tilapia in Israel. Bamidgeh, Bull. Fish. Cult. Israel, 18, 67-80.

GOSWAMI S. V., SUNDARARAJ B. I., 1971. In vitro maturation and ovulation of oocytes of the catfish, Heteropneustes fossilis (Bloch) : Effects of mammalian hypophyseal hormones, catfish pituitary homogenate, steroid precursors and metabolites, and gonadal and adrenocortical steroids. J. exp. Zool., 178, 467-478. 
KATZZY., ECKSTEIN B., 1974. Changes in steroid concentration in blood of female Tilapia aurea (Teleostei, Cichlidae) during initiation of spawning. Endocrinology, 95, 963-967.

KATZ Y., ECKSTEIN B., IKAN R., GOTTLIEB R., 1971. Estrone and estradiol-17 $\beta$ in the ovaries of Tilapia oureo (Teleostei, Cichlidae). Comp. Biochem. Physiol., 40B, 1005-1009.

OZON R., 1972. Estrogens in fishes, amphibians, reptiles and birds, 390-413. In IDLER D. R., Steroids in nonmammalian verfebrates. Acad. Press, New York and London.

REINBOTH R., 1972. Hormonal control of the teleost ovary. Am. Zoologist, 12, 307-324.

YARON Z., TERKATIN-SHIMONY A., SHAHAM Y., SALZER H., 1977. Occurrence and biological activity of estradiol-17 $\beta$ in the intact and ovariectomized Tilapia aurea (Cichlidae, Teleostei). Gen. comp. Endocr., 33, 45-52. 